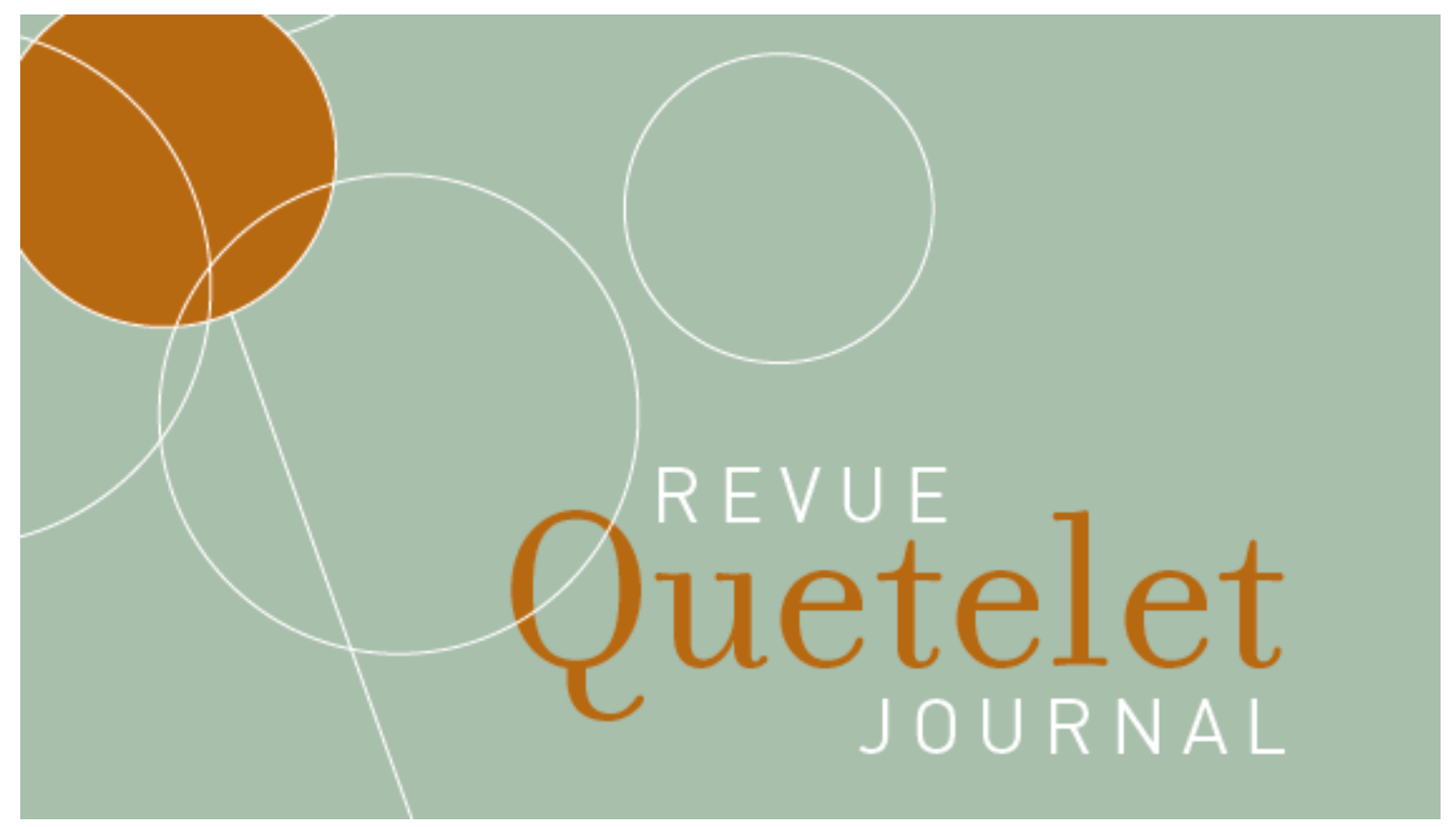

Vol. 7, n² , avril 2019, pp. 101-133

DOI : 10.14428/rqj2019.07.01.04

ISSN: 2593-9157

\title{
Transnational analysis of local fertility: A spatial organisation depending on metropolitan contexts and national borders
}

Mathieu Buelens

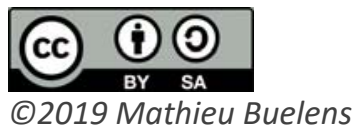

This work is licensed under a Creative Commons Attribution-NonCommercial 4.0 International License. You can share, adapt the material for non-commercial purposes provided that you give appropriate credit and indicate if changes were made. For details see https://creativecommons.org/licenses/by-sa/4.0/

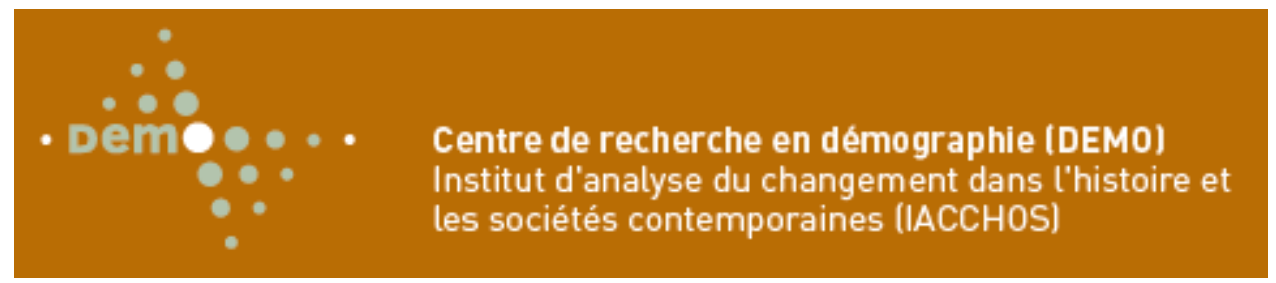





\title{
Transnational analysis of local fertility: A spatial organisation depending on metropolitan contexts and national borders
}

\author{
MATHIEU BUELENS ${ }^{1}$
}

\begin{abstract}
Résumé
La seconde transition démographique n'a pas effacé les différences spatiales en termes de fécondité en Europe du Nord-Ouest. Ainsi, il existe une distinction claire entre les États les plus au Nord et à l'Ouest du contient et les autres, ainsi que des différences intra-étatiques. Malgré la difficulté de rassembler des données comparables à une échelle spatiale fine pour plusieurs pays, cette étude propose à une échelle locale une comparaison transnationale de l'intensité et de la temporalité de la fécondité en Europe du Nord-Ouest. Elle examine la cohérence des modèles de fécondité sur territoire et détermine les échelles prépondérantes de leur organisation spatiale. La méthodologie consiste en une analyse par composantes principales appliquée aux taux de fécondité par classe d'âge pour 5376 entités locales reparties dans sept pays d'Europe du Nord-Ouest. De cette première analyse est déduite une typologie des entités spatiales selon leur fécondité.

Les résultats donnent à voir des modèles de fécondité contrastés en Europe du Nord-Ouest. C'est surtout la temporalité qui distingue les modèles de fécondité, tant au sein de la zone d'étude en générale qu'au sein de chaque pays séparément. D'un point de vue spatial, ces modèles de fécondité contrastés sont organisés selon l'action conjointe de deux éléments: les métropoles et les frontières nationales. Les environnements urbains sont dissociés du reste de leur contexte national. De plus, à l'échelle intra-urbaine, une triple distinction apparait : la fécondité est faible et est la plus tardive en centre-ville ; elle est la plus élevée avec des calendriers très dispersés dans les quartiers défavorisés et enfin elle est relativement forte mais bien plus concentrée autour de 30 ans en banlieue. Les résultats révèlent également l'importance du niveau national, auquel correspond $65 \%$ de la variance de l'intensité de fécondité entre les entités locales. Cela suggère que des facteurs nationaux doivent avoir une influence majeure sur l'intensité de la fécondité. L'utilisation de l'échelle nationale pour étudier l'intensité de la fécondité uniquement est
\end{abstract}

1. Université Libre de Bruxelles (ULB), Brussels, Belgium. 
ainsi en partie justifiée. Cette analyse démontre aussi l'intérêt des études locales des comportements féconds en milieu urbain.

\title{
Mots-clés
}

Analyse spatiale, modèles de fécondité, fécondité par âge, villes, contextes locaux.

\begin{abstract}
The second demographic transition has not erased spatial differences in fertility patterns in northwestern Europe. A state-level distinction exists between northern and westernmost European countries, on one hand, and the rest of the continent, on the other hand, as well as intra-national distinctions. Despite the difficulty of gathering comparable data at a fine spatial level in different countries, this study presents cross-national and local spatial distribution of fertility intensity and timing in northwestern Europe. The goal is to examine the coherence of fertility patterns and determine the overriding scales of their spatial organisation. The methodology consists in a principal component analysis on age-specific fertility rates (ASFR) of 5'376 local units in seven northwestern European countries. Local units are then gathered in clusters.

The results show contrasted fertility patterns in North-Western Europe. Differences in fertility timing are more important than differences in fertility intensity for both spatial units in the study area in general and within each country separately. From a spatial point of view, these contrasting fertility patterns are organised according to two existing levels: the metropolitan and the country level. Urban environments are isolated from the national context their embedded in. Additionally, a triple distinction appears within metropolises. Fertility is low and the latest in city centres. Fertility rates are the highest and dispersed through childbearing ages in deprived urban neighbourhoods. Finally, fertility is relatively high but with a narrow distribution through in suburban areas. The national level is relevant for $65 \%$ of the fertility intensity related variance between local units. It suggests decisive influence of national factors on fertility intensity. Cross-country analyses of fertility level are thus partly legitimated. However, this analysis also calls for better understanding of local fertility behaviours in metropolitan contexts.
\end{abstract}

\section{Keywords}

Spatial analysis, fertility patterns, age-specific fertility rates, urban contexts, local level.

\section{Introduction}

In western Europe, changes in fertility since the mid-1960s are understood as part of the Second Demographic Transition (SDT): a narrative connecting shifts in values and attitudes affecting partnership, reproduction and family. The SDT is a framework used to describe, among 
other phenomena, the secularisation of society, the rise in individualistic values and the promotion of (women's) emancipation and self-fulfilment through work or economic independence rather than through marriage and family, each eroding the traditional view of the family (see Lesthaeghe, Van de Kaa, 1986; Van de Kaa, 1987, 1994).

Despite some authors' suggestions (Roussel, 1992; Jones, 1993; Adveev et al., 2011), the SDT is not rendering international and local differences in fertility patterns obsolete. The «transition» part of the term «SDT» should not be understood as indicating a uniform and unidirectional movement towards a final state (Kuijsten, 1996; Sobotka, 2008b).

The literature shows that across countries differences in fertility-related behaviour have remained roughly stable since the 1970s (Decroly, Grimmeau, 1996; Coleman, 2002; Billari, Kohler, 2004). Behind a low (sub-replacement) average European fertility rate, with first births now occurring later than ever (28.7 years in the $\mathrm{EU}^{2}$ ), social and spatial differences persist even if low in absolute terms (Kuijsten, 1996; EkertJaffé et al., 2002; Douglass, 2007; Sardon, 2009).

Hence today, on a spatial level, a clear distinction is observed between the northern and western European countries and the rest of the continent, where even lower fertility is displayed (Lesthaeghe, Permanyer, 2014; Klüsener et al., 2013), as well as intra-national contrasts in fertility patterns. The latter, which some see as disappearing within regions of the same country (Basten et al., 2011; Watkins, 1991), are analysed for northern and western European countries as the product of regional disparities, (country-specific) socio-economic differences, or both, for instance in Belgium (Costa et al., 2011), the Netherlands (Sobotka, Adigüzel, 2002), France (Desplanques, 2011), Britain (Fiori et al., 2014), western Germany (Hank, 2001), Finland (Valkonen et al., 2008) or the Nordic countries (Kulu et al., 2007). These studies offer keys to understanding geographical variations and the added value of spatial analysis.

While contrasts in fertility patterns within individual nations have attracted significant attention, there are few cross-country studies analysing local differences of fertility in various countries. In Decroly and Vanlaer (1991) and Decroly and Grasland (1992) regional fertility intensity was analysed for European countries (but not differences in timing). National borders emerge in their results proving that the biggest differences in total fertility rate tend to be between rather than within coun-

2. Eurostat news release, «15 May 2015: International Day of Families», http://ec. europa.eu/eurostat/documents/2995521/6829228/3-13052015-CP-EN.pdf/7e9007fb3ca9-445f-96eb-fd75d6792965. 
tries. Urban regions have a lower fertility rate albeit approaching the national average (Grimmeau, Decroly, 2003). However, the urban context is not well considered with the regional units examined in these studies ( 800 '000 inhabitants on average). Data are now available at a much more local scale for both the timing and intensity of fertility.

\section{A local and transnational analysis of age-specific fertility rates}

This paper analyses the geography of current fertility habits from a transnational comparative perspective at the local level. The goal is to examine spatial coherence in fertility and to determine the overriding scale of territorial organisation for fertility patterns in northwestern Europe. This study thereby questions the usefulness of a literature focused on the cross-country analysis of low fertility (in which local variations are often supposed to be negligible within a country (Kulu et al., 2007)) for understanding fertility behaviours in Europe. The next two sections detail this study's space as well as data choice and availability, followed by the methods used.

\section{Study space}

When studying local differences, most of the literature is limited to a single country at a time. Studying a transnational space on the local scale is the only way to emphasise the hypothetical primacy of internal contrasts over country-specific patterns. Indeed, focusing on both scales places intra-national differences into perspective with international ones with no preconception of a predominant territorial organisation.

This paper uses the age-specific fertility rates (ASFR) of 5'376 local units in seven northwestern European countries: Belgium, Denmark, Germany, Luxembourg, the Netherlands, (metropolitan) France, England, and Wales. In 2010, this study space was home to 233 million individuals, more than 47 million of whom were women of childbearing age. 
FIGURE 1a Total Fertility Rates in northwestern European countries (1960-2015)

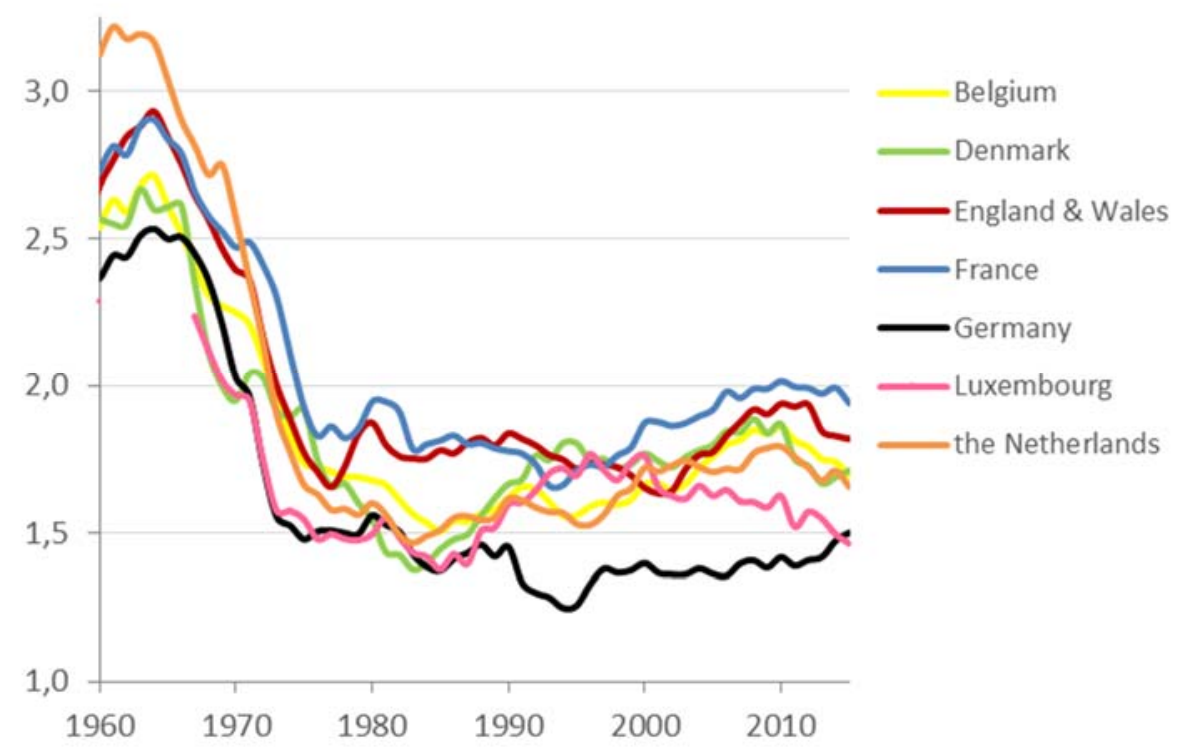

Figure 1b Mean Age at Maternity in northwestern European countries (1960-2015)




Between these seven countries, contrasts in fertility exist. The crosscountry convergence hypothesis is not supported by the evolution curves for total fertility rates (TFR) and mean age at maternity (MAM) (Figures 1a and 1b), nor by the evolution of those two basic indicators' coefficients of variation (Figure 2). At best, these show a common trend towards diminishing intensity until the 1970s, a slight increase at the beginning of the new century, and 40 years of ongoing postponement of timings.

FIGURE 2 Fertility intensity and timing variations through northwestern European countries (1970-2015)

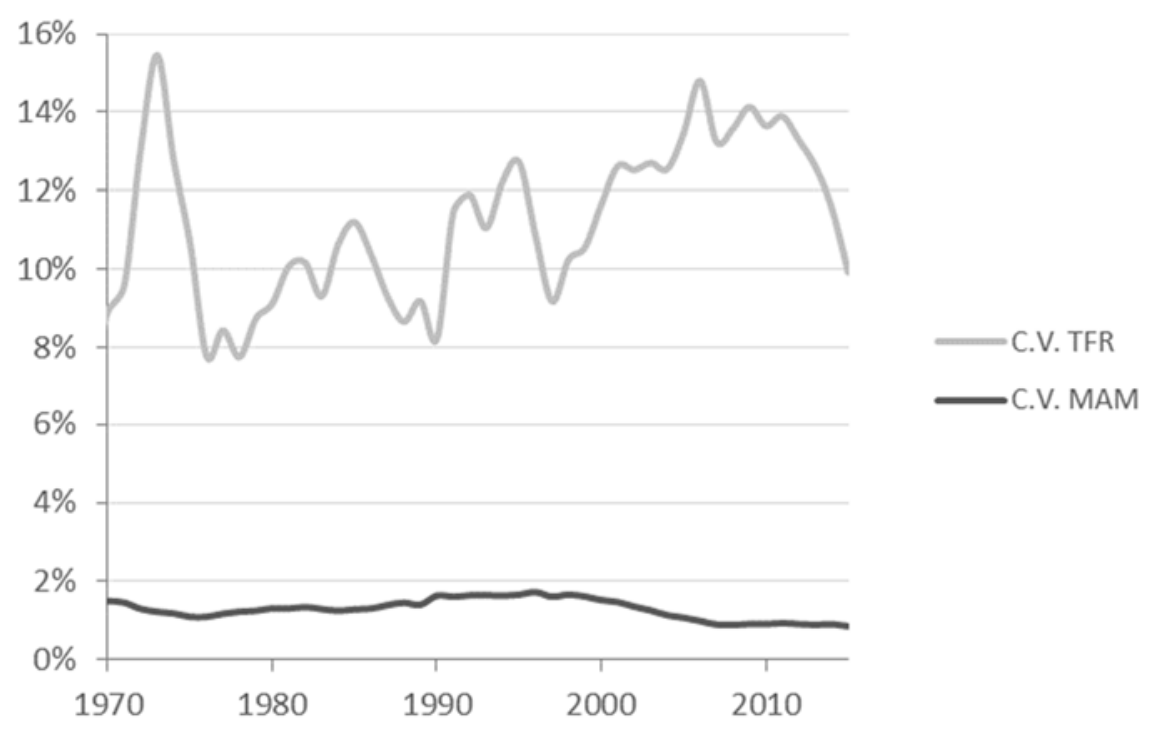

The level of analysis for this study is the lowest common in every country in order to promote meaningful comparison and analysis of local variations. In Belgium, Denmark, and the Netherlands, ASFR are available at a comparable municipality level. These countries' municipalities are home to $20^{\prime} 000$ to $60^{\prime} 000$ people on average. These are comparable to cantons in France and Luxembourg, where municipalities are roughly ten times smaller. A smaller administrative subdivision (the arrondissement) is nevertheless used for the three biggest French agglomerations. This way, the dispersion of territorial unit size is reduced and fertility pattern differences within major cities might be observed like within the Brussels region and its 19 municipalities. In contrast, the least populated units (fewer than 420 women of childbearing age) are merged with 
comparable, contiguous units from within the same country until they reach the 420-woman threshold defined by a changing gradient in the units' population distribution. This will prevent hypothetical statistical hazards and avoid disruption of graphic representations.

It has to be kept in mind that the scale of analysis influences the results: the smaller the unit, the more extreme the local values. The opposite is just as true: the broader the regions, the greater the risk of concealing internal variations behind an average. Hence Desplanques (2011), in analysing French regional TFRs, highlighted the difference between Paris, the department with the lowest fertility, and Seine-Saint-Denis, that with the highest, both part of the Île-de-France region.

In England and Wales, data are available at the wider district level: each unit hosts more than 160 '000 people on average. In Germany, data are only available for 421 territorial units (Kreise), Thus reducing crosscountry comparability. However analysis weighted by population overcome the problem. Hence, in the following analysis, in the example of a region with double the population of another, ASFRs of the first one are contributing twice as much to the national/type averages than those of the second. For more accuracy, it is not the global population but the number of women of childbearing age that has been chosen for weightings.

For England, the local unit grid is more similar to other countries than it seems at first glance. The most populated areas are divided in such a way that the largest districts, like Birmingham and Leeds, roughly present the same population as the largest Danish or Dutch municipalities. London is divided into «boroughs» comparable to Paris' arrondissements. It is only the least densely populated areas that are aggregated in, hopefully cohesive, wider districts. Germany poses a problem as its biggest cities do not present any internal division and consequently heavily influence the weighted analysis. Regional variations might also be obscured by Kreise averages. However, Hank (2001) has been able to identify regional and local differences between higher fertility in the northwest and south and very low fertility in university towns in western Germany using this same level of analysis. In addition, the urban-rural differentiation is still observable as cities are isolated in Stadtkreise, often surrounded by their namesake Landkreis. 


\section{Data and methodology}

If multi-country studies at a fine spatial level are lacking, it is partly due to the poor availability of comparable data. Large multi-national databases such as Eurostat, the European Social Survey, or the European Values Study gather few indicators at the intra-national level, and when they do, the indicators are rather simple and for large spatial units. For instance, Eurostat's database gathers births attributed to women in fiveyear age groups at the NUTS 3 level $^{3}$. Passing through national statistics offices is a laborious enterprise as many do not have an open-access policy. Additionally, each office defines the indicators it collects. Only the most common indicators are thus available for comparison. Finally, pre-processing 4 is needed before data from different sources can be compared.

For this study, it had to be decided whether to focus solely on the intensity of fertility. Fertility is a complex phenomenon and the TFR (the most common indicator for intensity) alone is not enough to understand differences in fertility patterns, especially with the diversification of family formations and birth contexts (marital or non-marital, with or without cohabitation) a feature of the Second Demographic Transition (see Lesthaeghe and Van de Kaa, 1986; Van de Kaa, 1987). Considering the timing of fertility in addition to its intensity is, if not enough to describe fertility in the SDT, at least better in terms of understanding the differences in women's childbearing careers.

Despite being quite simple, ASFRs are valuable because they are used to calculate two common summary indexes of periodic fertility. TFR, which gives an idea of the intensity of fertility by representing the average complete number of children a woman would have so long as the conditions remain the same through her entire childbearing period, and mean age of mother at childbirth (MAM) offers a general idea of fertility tim-

3. The Nomenclature of Territorial Units for Statistics (or NUTS) is a Eurostat established subdivision of countries for statistical proposes. The different levels usually correspond to existing national administrative subdivisions. The NUTS3 level contain between $150^{\prime} 000$ and $800^{\prime} 000$ inhabitants on average and correspond to French departments and German Kreise. The wider NUTS2 level correspond to the 22 regions in metropolitan France and the 41 Regierungsbezirke in Germany.

4. For example, Danmarks Statistik has records of births for mothers between 10 and 69 years old, at each age. At the Kreise level in Germany, Destatis provides birth number aggregates by age group from under 20 to over 40 , the last age group running from 40 years onwards. Their distribution between older age groups (40-44 and 45+) have been estimated from 2010 NUTS 2 data, at which level this age group distinction was available. 
ing. Nevertheless, with no information on dispersion, MAM does not accurately reflect the timing of births. Hence, exceptionally high teenage pregnancy rates could be hidden if mixed with unprecedented late fertility in a region.

Additional variables could provide a better picture of fertility habits, for instance, age at first birth as an indicator of childbearing postponement. But those data are not available at the local level for this study space. It must be kept in mind that the unavailability of better variables to illustrate SDT trends results in poor descriptions of fertility habits. However, as this study aims to describe the overriding scales of variation in fertility habits, not the habits themselves, this problem is minimised.

To obtain the ASFRs, the multi-annual ${ }^{5}$ average number of births attributed to women in a specific five-year age group is divided by the same year's average number of women in the group. The data come from national statistics offices and were downloaded for all countries, except Belgium, where a specific request had to be made.

A principal component analysis was applied to ASFRs. This statistical method extracts original information from the fertility rates of the seven five-year age groups (from less than 20 to 45 and over) and aggregates it in a minimum of axes. No rotation has been carried out. These axes (or components), gathering more information than the TFRs and MAMs on their own, were then used to build a fertility pattern classification ${ }^{6}$. Both summary indexes and women population in childbearing age (Pop) are projected (after standardising) as illustrative variables to make it easier to understand what the components represent.

\section{More timing than intensity differences between fertility patterns}

The most significant component, describing $41 \%$ of the total variance, opposes municipalities where the oldest age groups have relatively high fertility to those where fertility is low at the older ages but high among women under 25 years old (see Figure 3). This axis is well but not perfectly correlated with the MAM (0.7) as it mainly isolates late fertility

5. To minimise statistical hazards due to small occurrence and/or population in some territorial units, the ASFRs are based on average numbers for three consecutive years, around 2010.

6. Using Ward's hierarchical clustering method (square distance of the barycentre). 
but not so much early fertility. It is interesting to note the proximity of the three oldest age groups in terms of this (and the following) component. This means that places where fertility among women 35-39 years old is high also present high fertility among women 40-44 and 45 and over.

\section{FIgURE 3 Projection of ASFRs on components 1 and 2}

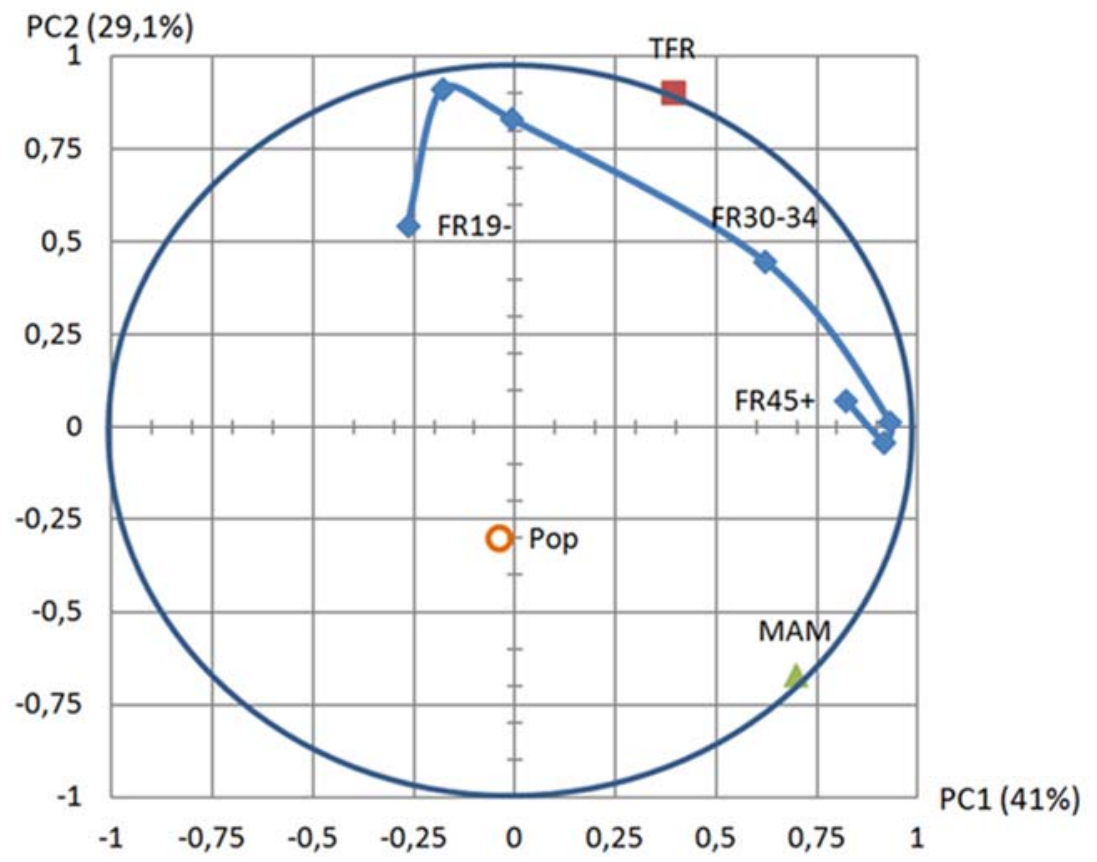

As Figure $4^{7}$ shows, these places specifically are the city centers of the main French metropolises in particular, and the largest cities as a whole, like London, Amsterdam, and municipalities around Copenhagen. Ger-

7. This and the following maps are distorted. The size of each spatial units on the maps does not represent its surface area but depends on its population size (here the number of women of childbearing age). To get this shape of spatial units, a grid is applied on the original shape then distorted according to the population each cell of the grid contains. The population of the cells is known using the Gastner/Newman (2004) diffusion-based algorithm. Consequently the more populated places are, the larger they will appear on the maps and thus be more noticeable. That way, when proceeding spatial analysis, attention focuses on places with the largest population. With a classic representation cities like Brussels would have been barely visible at this level. This representation also helps better understand results of weighted analysis (like weighted mean) because the more visible a region, the more it contributes to the final result. 
man, Belgian, British, and Danish second- or third-order cities (e.g., Stuttgart, Dresden, Aachen, Ghent, Charleroi, Liverpool, Leeds, Sheffield, Aarhus) have lower scores than those of the largest urban municipalities of their country but higher scores than those of nonurban areas. This might be due to a large unit effect (including both the city and its suburbs), but more likely to lower fertility in these cities in general or to higher younger fertility pulling towards negative scores, or both. Indeed, this component highlights spaces where fertility is high for older women and/or high compared to younger women.

However, even in a low-fertility context (Germany), cities are isolated from their surroundings by displaying a relative higher fertility among older women. Nonurban places above the average are roughly in the Netherlands (whose borders mark clear discontinuities with neighbouring countries), Southeast France, Brittany, and the Pays de la Loire. In contrast, the lowest fertilities of women 35 years of age and over are in rural parts of East Germany, the peripheral regions of Germany in general, Belgium, and England.

The second component ( $29 \%$ of variance) segregates at best municipalities according to the remaining information. It highlights stronger fertility in relatively young age groups (see Figure 3). The older groups are almost not significant here because they were on the previous axis. The two extreme age groups are not the most distant due to the lower occurrence of births at both extremes of the childbearing period. Places where fertility levels are the highest among the younger age groups are also those where fertility is highest in general (PC2 90\% associated with TFR). It is, therefore, no surprise that in Figure 5 Germany stands out from the rest with very negative scores (German national average of 1.39 children per woman).

When cities are isolated from their surroundings, they also present negative scores. This is both attributable to fertility largely taken up by older age groups ( $c f$. above) and a lower fertility at their core. This phenomenon is visible in each country except Belgium. Indeed, scores in Antwerp, Liège, Charleroi, and central Brussels seem to indicate higher fertility in Belgian cities. 
Figure 4 Local units scores on the first component (late fertility index)

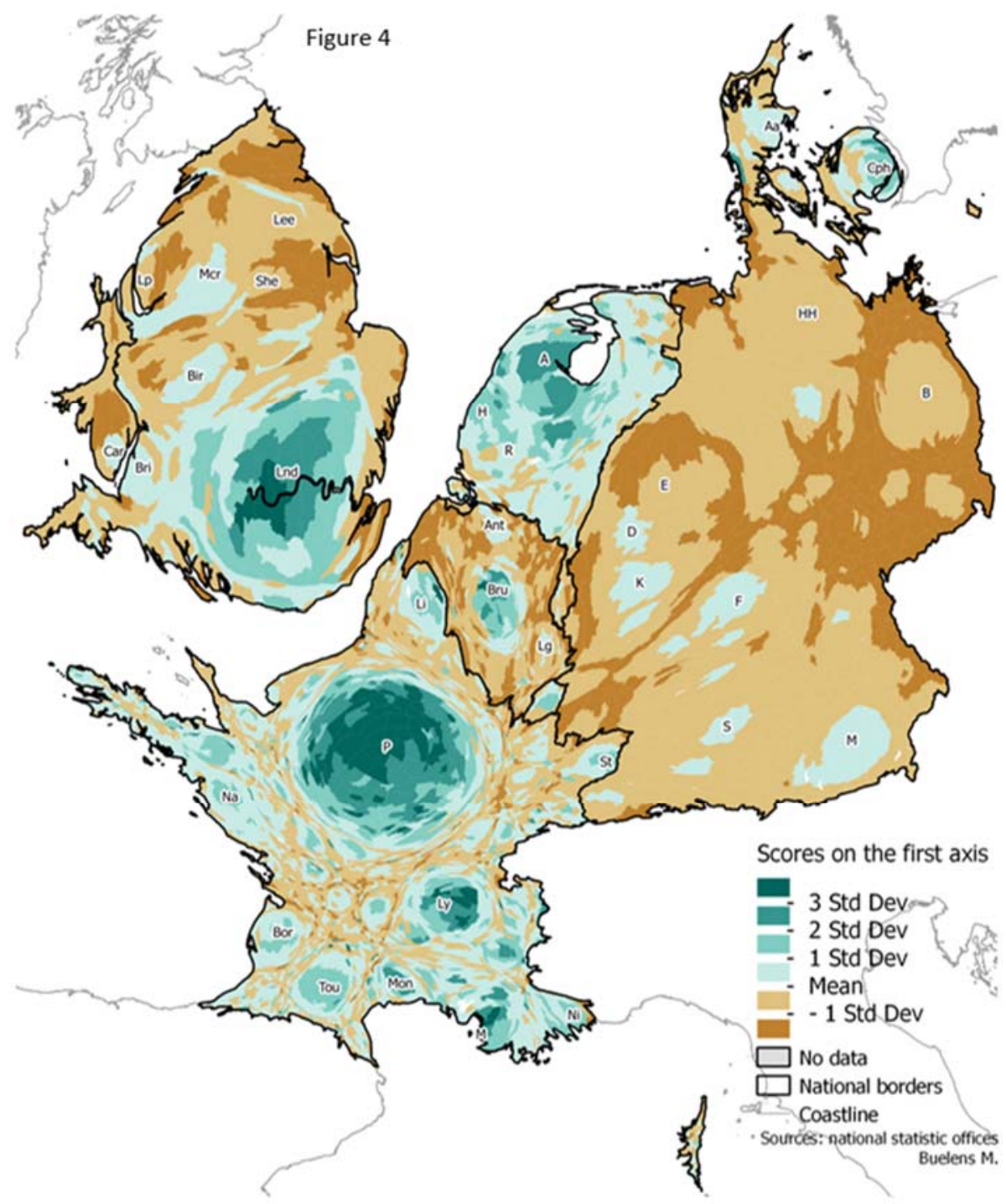


FIGURE 5 Local units scores on the second component (intensity of fertility index)

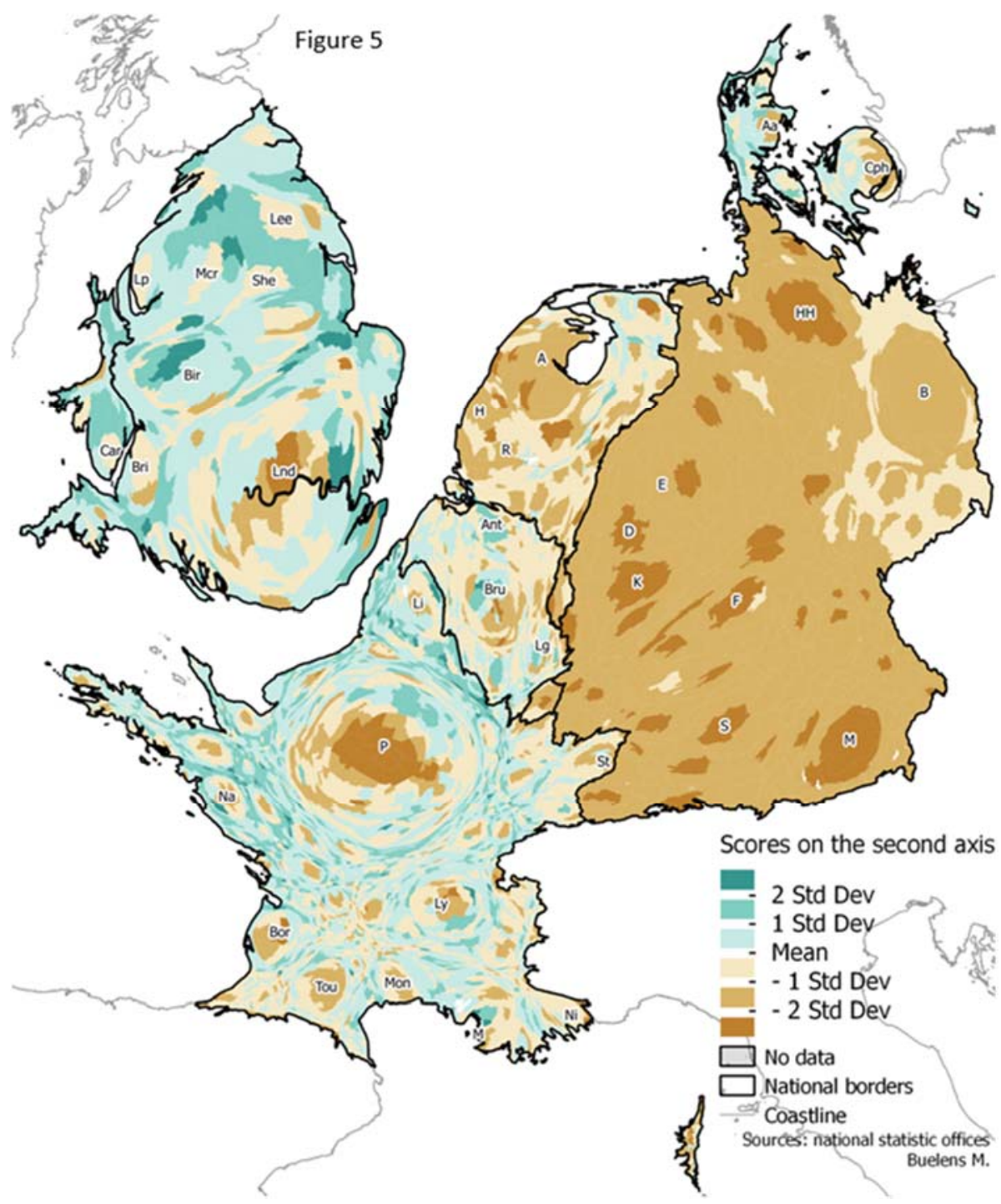

Exceptionally positive scores (women 20-30 years old with high fertility rates) and the highest TFRs are found in neighbourhoods of Dunkirk (where it exceeds five children per woman, which calls for caution on this data) and in other cities in Nord-Pas-de-Calais, deprived central municipalities in the Brussels area, Seine-Saint-Denis, northern districts of Marseille, eastern parts of both Lyon and London, and some manufacturing centres in Britain. Low and high TFRs are sometimes cotermi- 
nous, marking clear discontinuities such as that created by the Parisian ring road. These discontinuities may consist of a difference of more than one child (for example, in Brussels 1.37 between Dilbeek suburbs and the more central Molenbeek, where fertility is higher).

Municipalities around Rennes (Brittany) and Nantes (Pays de la Loire) also display particularly positive scores on the «high fertility at younger ages» axis, but they also do so on the first component, which results in a high TFR. In Britain, the relatively high fertility is largely due to younger age groups as districts score high on the second but low on the first axis, cities excluded. Exceptionally negative scores are located around Menton and Monaco on the French Riviera and in university towns in south Germany (e.g., Heidelberg, Würzburg).

\section{Figure 6 Local units scores on the first and second components}

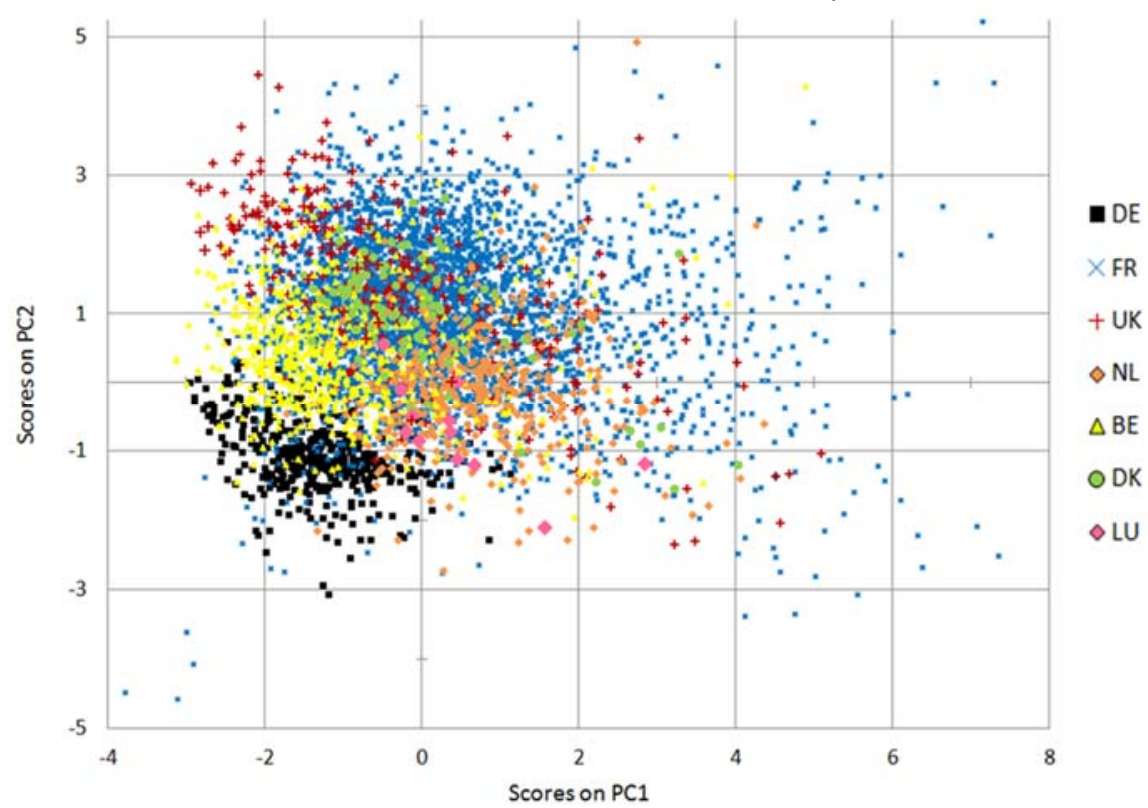

The national organisation of fertility intensity in northwestern Europe is pointed out by the projection of local units on those axes (Figure 6). In general, they are organised in country-specific clouds, or layers, along with the second component (intensity-related). Starting from the bottom, the German observations display the most negative scores. Luxembourg follows, then Belgian and Dutch municipalities presenting average scores. In Belgium, fertility is more strongly the product of women before 25 (left of the first axis) than in the Netherlands (positive scores 
on PC1). Danish municipalities present clearly positive scores on the second axis, and the French and the British national clouds even more so (with higher TFRs). Once again, they are distinct from each other by fertility led by younger age groups in England and Wales than in France. The overwhelming presence of cities on the right side of the graph is a reflection of later urban calendars.

If each country had been analysed separately, the first component would, here again, have predominantly segregated timings. National clouds indeed stretch along the first axis more than the second 8 .

\section{FIGURE 7 Projection of ASFRs on components 2 \& 3}

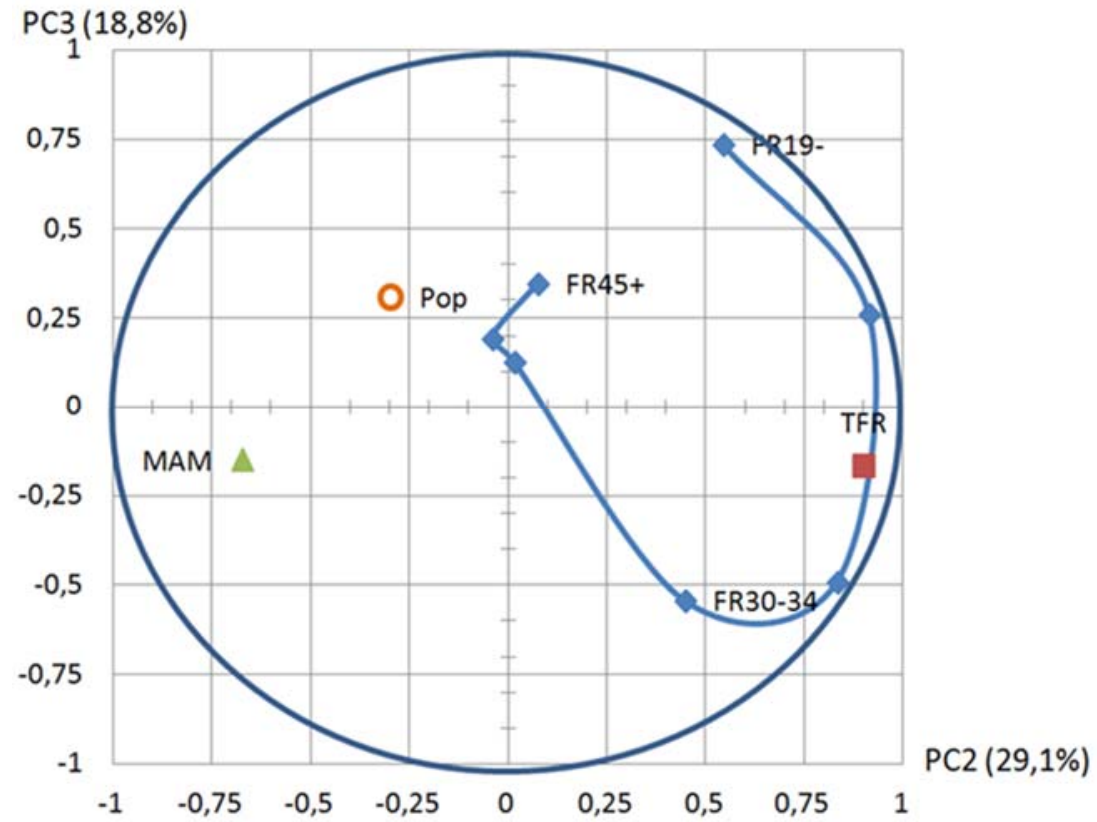

After isolating places with high «late» fertility (PC1) and high relatively young fertility (PC2), the third in importance and last significant component distinguishes places where fertility is high at both ends of the childbearing period from those where women 25-35 years old are responsible for most births. This component is associated with the TFR for only $17 \%$ of its total variance; it is thus not an intensity measure but,

8. In a prior analysis of a smaller number of countries (Belgium, Denmark, The Netherlands, and Britain) the intensity-related component was relegated to third position because of small TFR differences between those four countries. 
with its «U» shape (see Figure 7), could be considered as a dispersion measurement of fertility calendars around the average (MAM of 30.2 in the region), regardless of the intensity of fertility.

FiguRE 8 Local units scores on the second and third components

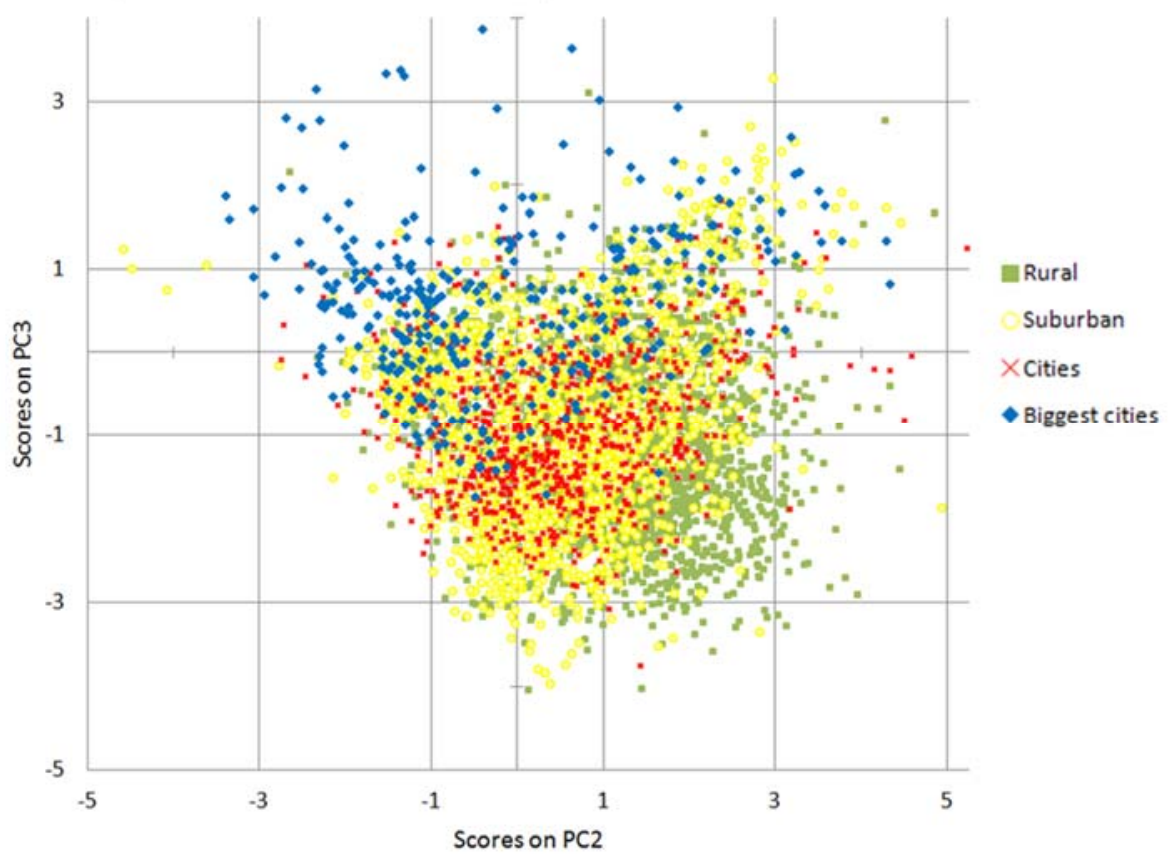

In Figure 8, this axis seems to oppose the biggest cities with rather positive scores to little-dispersed calendars around modal age groups in rural areas ${ }^{9}$. Mainly positioned in the lower right corner of the graphic, rural municipalities display both a clearly compacted and "productive» pattern: the exact opposite of the biggest cities, where extreme age groups have relatively high fertility rates. The biggest cities' cloud is much more scattered than the smaller cities' one due to the diversity of environments in metropolitan contexts (low fertility in the core, very high in some neighbourhoods). Displaying a high score on the third axis is, however, a common trend. Other (smaller) cities and suburban places

9. Eurostat's Degree of Urbanisation classifies local administrative units in three categories based on 2011 population data: cities; towns and suburbs; and rural areas using criteria of geographical contiguity, density, and minimum population threshold on $1 \mathrm{~km}^{2}$ grid cells. 
present negative scores on the third component and fertility rates lower than in rural areas.

FIgURE 9 Local units scores on the third component (non-normativity of fertility index)

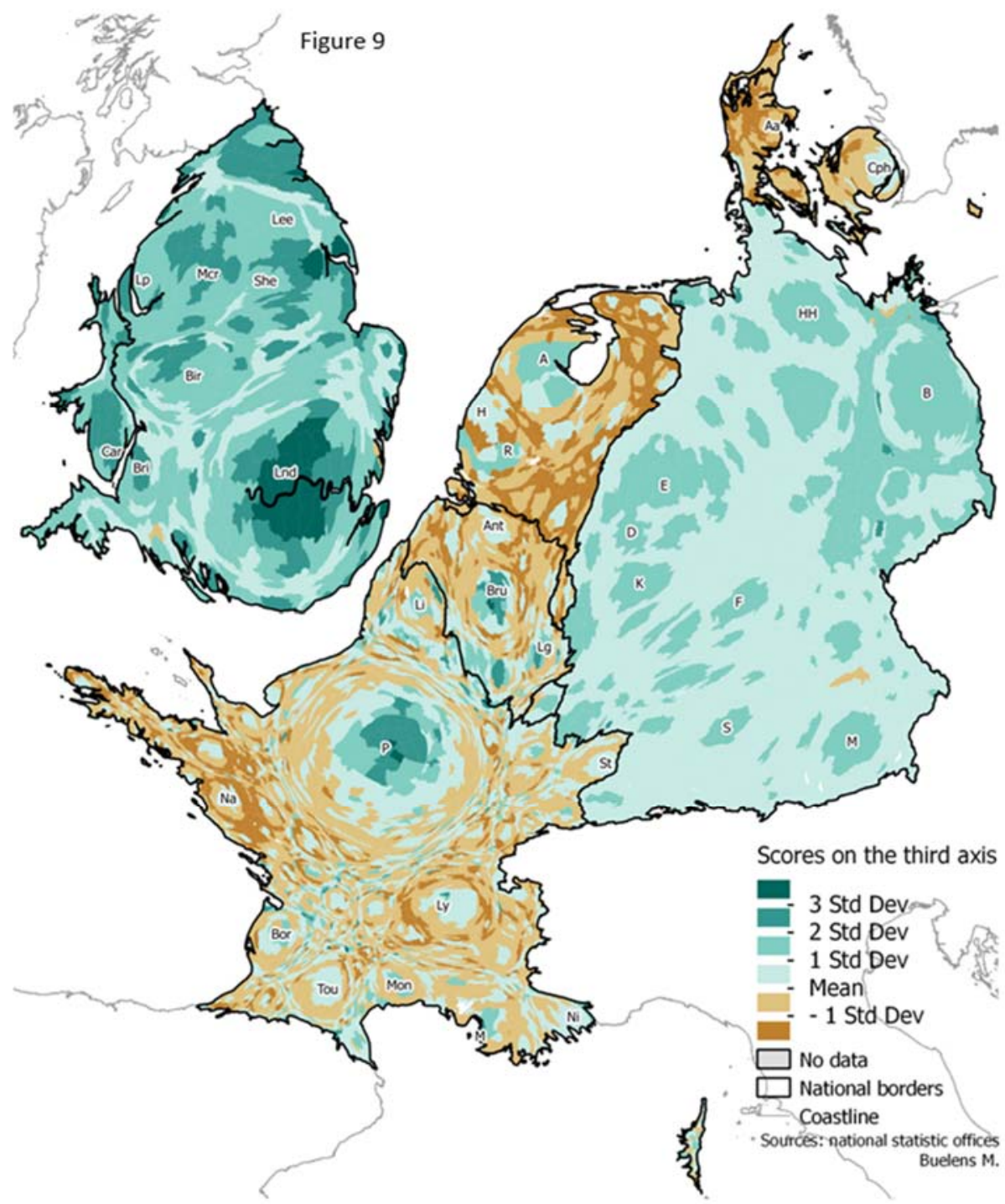

The proportion of births that are due to middle-aged women is the lowest in Inner London first and across the rest of Britain next. After that, the lowest proportions are in major cities, then in Germany including 
rural Germany ${ }^{10}$. Figure 9 suggests that on top of the urban-nonurban distinction, national influences must also be considered in fertility dispersion. Where data are available at an infra-urban scale, a concentric pattern is visible. The core presents the highest scores which then decrease to the local lowest in the suburbs. This is visible in (relatively) high- and low-fertility contexts, for larger or smaller cities.

In contrast, the most compact calendars are especially located in the north of the Netherlands, then in the rest of the country, and lastly in Jutland and northwestern France. Flanders and eastern France present above-average scores on this low-dispersion component.

\section{The singularity of the urban fertility pattern}

Figure 10 maps the fertility pattern classification based on the three described components (together accounting for $89 \%$ of the total variance in ASFRs). It spatially segregates urban from nonurban environments: the biggest cities are always isolated from their national or regional surroundings. Most of them (in every country but Germany and the UK) are gathered in the same (A) group and display very late and dispersed fertility calendars. The fertility intensity there is also low, only slightly above the average (the average being massively reduced by Germany). However, it is one of the least homogeneous clusters in regards to TFR. The fertility distribution curve (Figure 12) shows particularly low fertility rates for women around 25 years compared to nonurban women of the same age group. It peaks at 30 to 35 years, while the three oldest age groups account for almost a third of the total fertility (much more than the $19 \%$ on average). Consequently, the MAM is the highest of all types at 32 years even despite low fertility ${ }^{11}$.

10. It is difficult to know without further research how much this high dispersion of calendars in Germany is due to the size of the Landkreise units potentially mixing up various lower-level contexts.

11. The mean age of mothers at childbirth indeed rises automatically with higher fertility intensity. 
FIGURE 10 Fertility patterns classification




FIGURE 11 Main characteristics of fertility patterns types

\begin{tabular}{|c|c|c|c|c|c|c|c|c|}
\hline & Name & TFR & MAM & $\begin{array}{l}\text { Units } \\
\text { con- } \\
\text { cerned }\end{array}$ & $\begin{array}{l}\text { C.V. } \\
\text { TFR }\end{array}$ & $\begin{array}{l}\text { C.V. } \\
\text { MAM }\end{array}$ & $\begin{array}{l}\text { Pop. } \\
\text { con- } \\
\text { cerned }\end{array}$ & Fertility pattern \\
\hline A & Metropolitan & 1,81 & 32,0 & $5,2 \%$ & $4,6 \%$ & $1,0 \%$ & $10,8 \%$ & Very late; Dispersed \\
\hline B & Poor urban neighbourhoods & 2,52 & 30,3 & $2,4 \%$ & $1,7 \%$ & $0,3 \%$ & $2,5 \%$ & Highest fertility; Dispersed \\
\hline C & Suburban & 1,98 & 30,5 & $27,5 \%$ & $3,5 \%$ & $0,7 \%$ & $15,5 \%$ & Normative - late \\
\hline D & German cities & 1,47 & 31,3 & $3,3 \%$ & $4,2 \%$ & $0,6 \%$ & $11,2 \%$ & Late; Very low \\
\hline $\mathrm{E}$ & Nonurban - others & 2,06 & 29,6 & $38,3 \%$ & $3,7 \%$ & $0,5 \%$ & $11,0 \%$ & High fertility; Normative - young \\
\hline $\mathrm{F}$ & Nonurban - Britain & 2,07 & 28,7 & $11,8 \%$ & $3,0 \%$ & $0,9 \%$ & $15,8 \%$ & Young; High; Non-normative \\
\hline G & Nonurban - Germany & 1,41 & 30,0 & $11,4 \%$ & $4,8 \%$ & $1,2 \%$ & $33,2 \%$ & Very low \\
\hline & 7 countries average & 1,75 & 30,2 & 5376 & $20,4 \%$ & $3,8 \%$ & \multicolumn{2}{|c|}{$47,3 \mathrm{~m}$ women in childbearing age } \\
\hline
\end{tabular}

FIGURE 12 Fertility distribution through ages in urban fertility patterns types

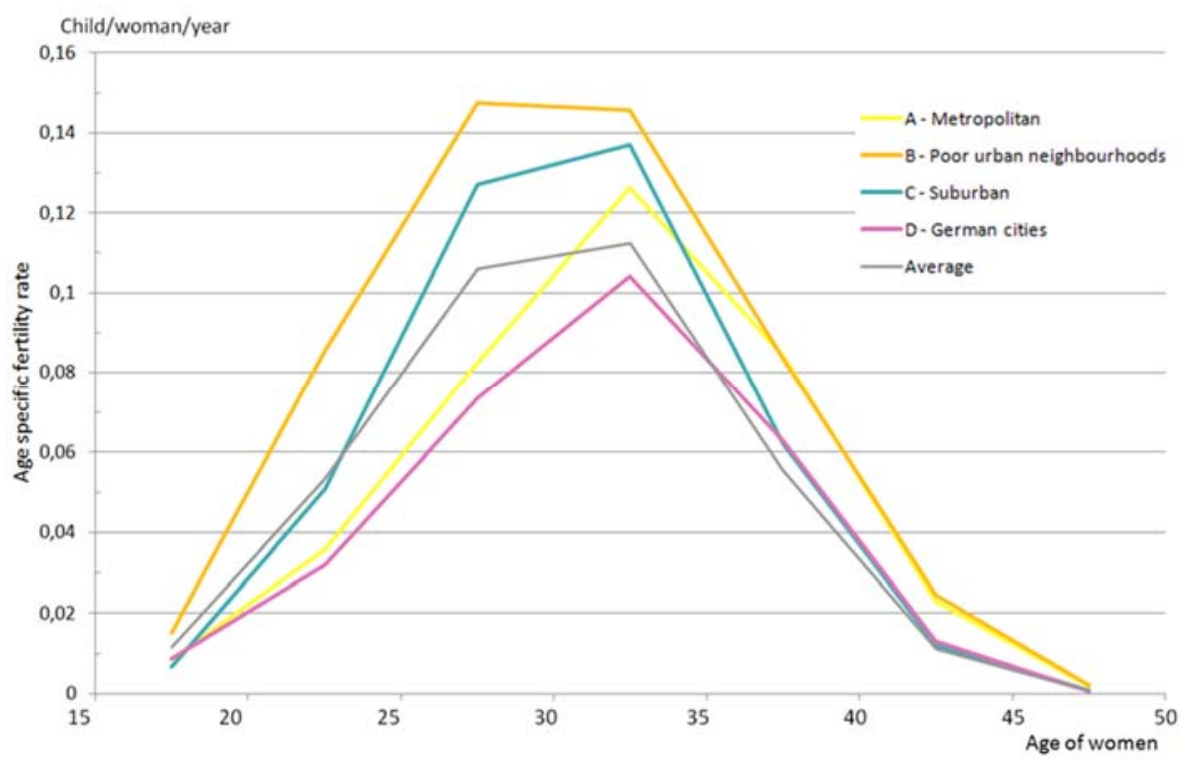

Metropolises are places of contrasts as the most "productive» pattern (group B; 2.52 children per woman) is displayed in urban environments as well. Their fertility curve is high at both extremes and symmetric around the 25 to 35 decades, plateauing at 0.15 child per woman per year. These municipalities and districts stand out for their exceptionally high score on the second component even if fertility is well above average at all ages (on each of the three components). The geography of this pattern, concentrated in the poorest neighbourhoods of the biggest cities (where infra-urban data are available) and other French cities like Béziers or Dunkirk implies a correlation with a low socio-economic level. The singularity of these two urban types is evident; together they 
form indeed the last group to merge with all the other units in the agglomerative clustering tree. Additionally, this last subgroup is the most coherent regarding both TFR and MAM.

In the immediate proximity of cities, suburban municipalities (group C) present very low dispersion of fertility calendars. Forty-seven percent of the TFR (1.98 children per woman) is attributed to the two middle-age groups. With a peak reached by 30 to 35 years old, the MAM is slightly later than the average. This pattern with rather little dispersion around the average is displayed around almost every city in regions where core and periphery are clearly subdivided administratively. It is also representative of most rural areas in the Netherlands. This homogeneity of fertility carriers raises questions about both the homogeneity of women in such places and the homogeneity of those places through countries.

German cities (cluster D) are distinguished from those in the other countries by their very low intensity. However, despite the national effect on the intensity, the distribution of fertility through age groups is very similar to the main urban type. This pattern is also visible in some Dutch and British second-order cities with lower intensity before 30 years leading to a lower TFR than the national averages. This low fertility is magnified by a sharper decrease after 35 years, which does not enable them to catch up to the volume of the other biggest cities.

FIGURE 13 Fertility distribution through ages in nonurban fertility patterns types

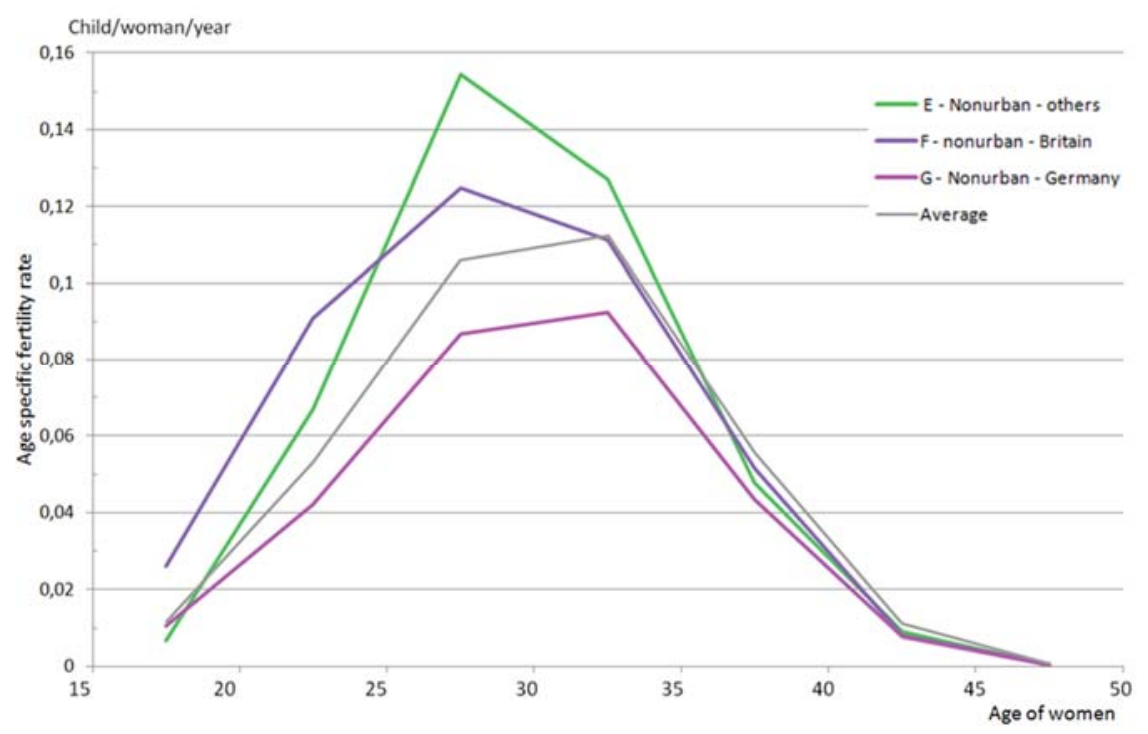


Apart from this double- (or triple-) layer urban differentiation, a «country effect» is indisputable for rural areas. Nonurban France, Belgium, and Denmark (group E) also present fertility pattern tightly concentrated between 25 and 30 years (Figure 13). It peaks at these ages (at 0.15 child per woman per year), which is five years earlier than patterns in urban environments. Fertility then drops after 30 almost as quickly as it rose between 15 and 25 . With 2.06 children per woman, it is also one of the most productive patterns.

Women of the two first age groups have the highest fertility rates in England and Wales (cluster F), the older ones then following the average distribution. This «bugle» at early ages makes this curve unique. It results in the second most "productive» fertility pattern of all, while surely the youngest (MAM of 28.7 years). The country effect seems preponderant as $84 \%$ of the women concerned are living in England or Wales. Nevertheless, only $57 \%$ of British women aged 15-44 are included in this group as this pattern does not apply in most urban areas. Interestingly, on the continent, this pattern is encountered in some peripheral rural regions of France, the past industrial Walloon axis, and its extension in Pas-de-Calais and other Belgian second-order cities. Indeed, Belgian cities have been highlighted for the high fertility of the younger age groups in the urban-core context (see scores on PC2).

Lowest fertility for nonurban young women is observed in German Landerkreise (group G) while older women in these have the lowest fertility of all in the study space. The distribution of fertility through ages rises slowly, as in the German cities, but plateaus between 25 and 35 years and decreases quickly until the 40-years-and-over group reaches a lower level than the under-20s. With 1.41 children per woman, this is the least productive pattern. Some of the largest cities of northern England presenting a lower and later fertility than in their regional context fall into this group. But they might present relatively different fertility behaviour as the cluster's TFR and MAM coefficients of variation are the highest of all (although still far under those of the whole study area). The group also gathers the biggest units. The «country effect» is clearly visible and indisputable here as well: ninety percent of women in this group live in Germany. 
Fertility intensity to be analysed at the country level, fertility timing depending on metropolitan factors?

FIGURE 14 Part of variance associated with fertility patterns classification

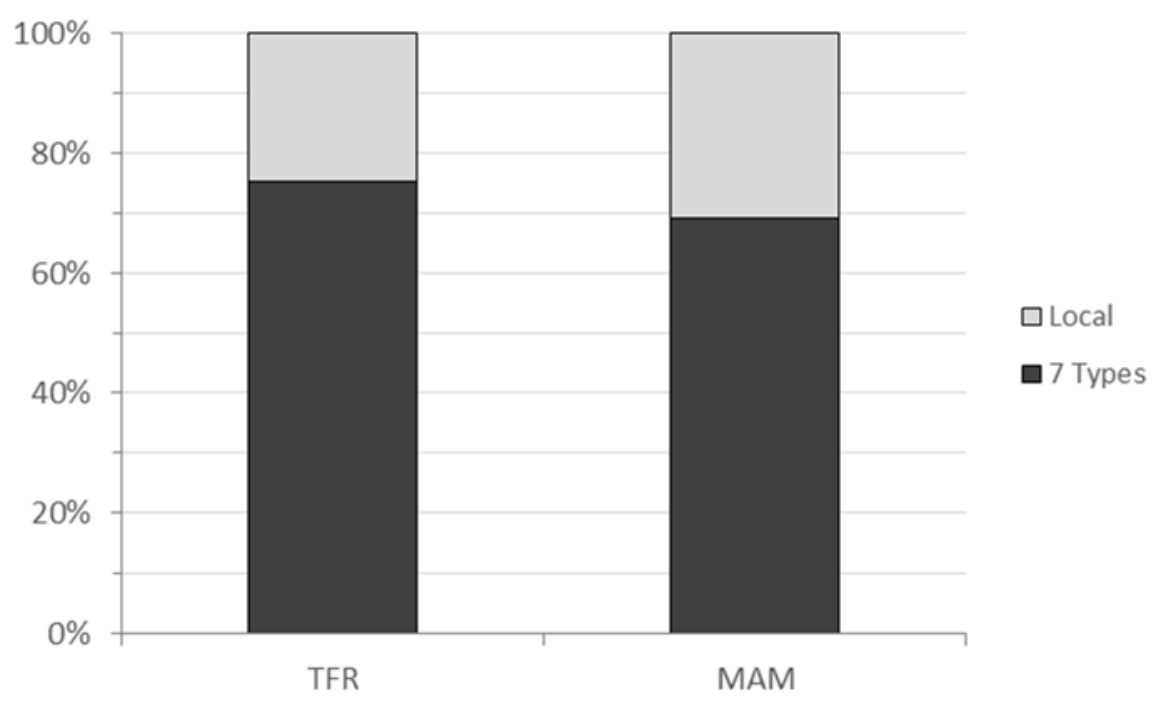

FIGURE 15 Cumulative part of variance associated with NUTS levels

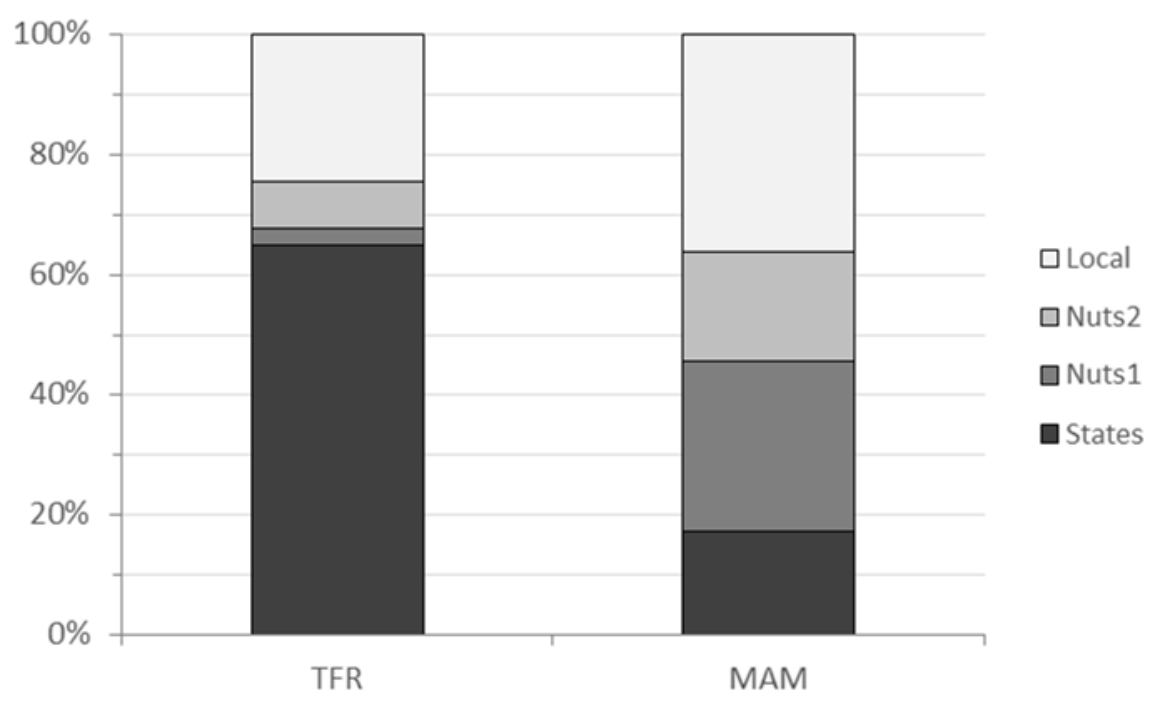


Observing the spatial distribution of the seven PCA-based types, it seems that two scales predominantly shape differences in fertility patterns in northwestern Europe. Focusing on these seven groups is enough to study $75 \%$ and $69 \%$ of the variance in 5,376 local TFRs and MAMs (Figure 14), respectively. The national level alone is associated with $65 \%$ of the total variance in TFR (surely because of Germany, where the TFR sits at 1.39, whereas in other countries it quickly rises (from 1.62 in Luxembourg and 1.80 in the Netherlands to 2.03 in France) but expresses very poor timing differences (Figure 15). Adding the NUTS 1 (49 regions) and NUTS 2 levels (198 provinces/departments/countries) only helps for an additional $10.5 \%$ of the total variance in TFR. The rest must be associated with other levels. This means that fertility patterns within the seven selected countries are mostly coherent from an intensity point of view but not from a timing point of view. On the other hand, within each country (if considered one at the time) fertility patterns differ in timing more than in intensity. In other words, fertility intensity is driven by national factors much more than tempo is. However, it would be an oversimplification to consider fertility intensity as organised solely at the state level and timing as driven by metropolitan contexts. Indeed, metropolitan environments were clearly visible on the CP2 map, CP2 being highly associated with TFR (Figure 5).

FIGURE 16 Cumulative part of variance associated with DGURBA classification within countries

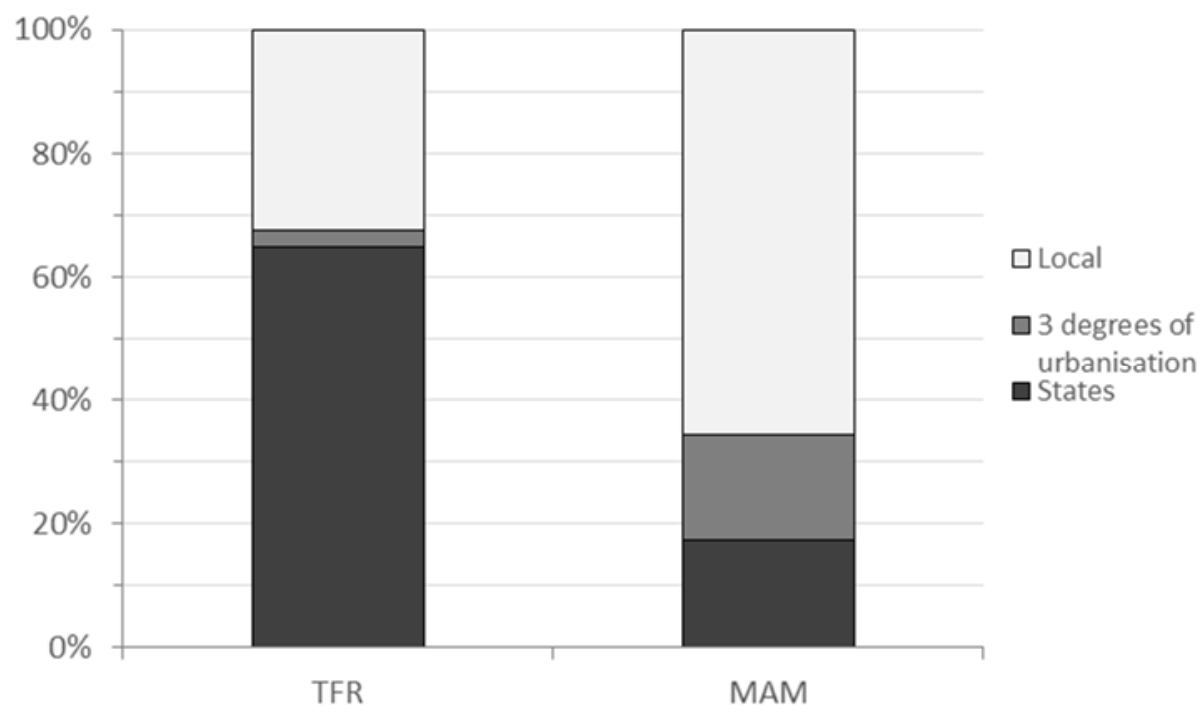


Arguably the factors affecting differences in the intensity of fertility in northwestern Europe should first be looked for among the factors exerting scopes of action at the national level (more about this below).

Eurostat's degree of urbanisation is not associated in great part with differences either in timing (14\%) or in intensity (3\%) (Figure 16). Even looking at this classification within each country separately does not help to understand variations in TFR or in MAM; both urban/suburban/ rural organisation and national organisation are associated with MAM variance for about $17 \%$ only.

Our results, however, strongly support previous findings of lower fertility in core cities (Fiori et al., 2014; Hank, 2001) and a delayed timing compared to the national average (Kulu et al., 2007; Wanner, 2000). Clear urban patterns have emerged through this analysis, with urban cores displaying lower and later fertility with greater spread of timings. The variety of contexts concealed behind each of the three Eurostat categories is too wide here, even within each country, to distinguish urban/ suburban/rural contexts. Indeed, it is not so much an urban-nonurban density differentiation that has been revealed above but the common organisation of fertility patterns across three different metropolitan environments. National and state capital cities and regional administrative centres («chefs-lieux») in France, as well as their British counterparts, are isolated from their surroundings, displaying a multi-layered spatial organisation of fertility patterns with fertility that is low and late at the urban core, highest and dispersed in deprived neighbourhoods, and relatively high in intensity and compact in tempo in the suburbs.

If countries account for an important part of the local intensity variance, the NUTS 1 and 2 levels seem to be the overriding scales for timing (Figure 15). However, closer analysis reveals that of the $28 \%$ of MAM variance associated with the NUTS 1 level, $11 \%$ are due to the simple fact that the Greater London and Île-de-France regions are defined at this level. If the NUTS 1 and 2 administrative levels seem important to explain timing differences, it is because they are most closely comparable with this metropolitan differentiation. 


\section{Discussion: Different patterns, organised at different levels, due to different factors}

This multi-country spatial analysis of fertility behaviour at the local level supports the idea of contrasting patterns, or models of fertility, throughout northwestern Europe. Each pattern displays its own curve for ASFRs. The differences were seen in both the timing and intensity of women's reproductive careers even if, in this study area, dispersion of women's fertility tempo is more important than variations in level. Indeed, the main pattern of opposition for discerning the ASFRs of 5,376 local units is a young-versus-old fertility axis. This supports the necessity of taking timing into account when studying fertility differences within nations. The results support the assumption that the Second Demographic Transition does not lead to homogenous fertility behaviour. Individuals, freer than ever before from the influence of religious institutions (see secularisation in STD theory in Lesthaeghe, Van de Kaa, 1986 or Lesthaeghe, Neels, 2002) and biological constraints (with the availability of contraception: see Bajos, Ferrand (2006)) are now more able to fulfil their fertility preferences. Nevertheless, it seems that there is still something else that is shaping fertility habits differentially. Whether this is due to the remaining material or institutional constraints (national or local) or to culturally determined «preferences», lifestyle "standards», or norms is beyond the scope of this analysis.

The results discussed throughout this paper have revealed differences in fertility patterns that match national borders. This calls for the consideration of a country effect when studying fertility behaviour. This corroborates Decroly and Grasland (1992) who highlight fertility coherence within states and major fertility discontinuities that correspond to political borders. The national context is presumably relevant in explaining low fertility in Germany, high fertility rates among young women in Britain, and compact timing in the Netherlands. In addition, national contexts seem to be valuable in understanding different spatial organisations of fertility patterns from one country to another: for example, Belgium's singularity of higher fertility before 25 years in the city centres and later calendars further away, in contrast to other northwestern European cities.

The organisation of fertility patterns at this level suggests the decisive influence of factors playing a role nationally. For now, the results allow us to hypothesise that factors with a national scope of action influence the spatial organisation of fertility levels. The literature proposes many 
such factors, especially those that are related to family policies such as financial transfers, parental leave, and childcare services. While each has been proven to have a positive influence on fertility intensity, there is a broad consensus that policies supporting parents to combine work with childbearing and so reduce the indirect costs of family formation (lost wage opportunities) have the greatest positive impact (Rindfuss et al., 2014; Luci-Greulich, Thévenon, 2013; Gomes et al., 2012; Thévenon, 2011; Prince Cooke, Baxter, 2010), in particular childcare options and availability (Castles, 2003; DiPrete et al., 2003). Policies also seem to impact on birth interval (Hoem, 1990) as well as fertility timing in general (see Kalwij, 2010; Thévenon, Gauthier, 2011). Watkins (1991) suggests other aspects of nation-building that contribute to the demographic convergence of provinces within western European countries, such as a nationwide standardised education system, the establishment of a common culture and language (allowing nationwide mass media broadcasting) (Klüsener et al., 2013), and the decline in provincial economic inequalities. Finally, Decroly and Grasland (1992) present a third hypothesis which sees nations as favoured spaces of circulation (internal migration), which leads to diffusion and transmission of fertility behaviours, to understand the fertility coherence in their study.

On one hand, our results partly legitimate studying fertility at the national level, but they also call for a better understanding of transnational fertility behaviours. Indeed, though this analysis, metropolises clearly escape the overriding national context no matter the country, like a sort of demographic parallel to the spatial organisation of the «archipelago economy» (Veltz, 1996) where, in a neoliberal competitive context, the biggest cities increasingly become interconnected nodes within a global economic network. This suggests that fertility in metropolitan regions is not as closely tied to the national context as it is in rural areas and smaller cities. However, rather than outweighing the national influence, such contexts point to a multi-layered influence through concomitance of national and lower spatial subdivision levels, as evidenced by the agespecific fertility distribution curve for German cities, paralleling other metropolises but with lower intensity at all ages.

Additionally, within those metropolitan regions, a triple distinction appears, with fertility that is low and late in the urban core, highest and dispersed through the ages in deprived neighbourhoods, and relatively high and normative in the suburbs. This common organisation of fertility patterns supports the hypothesis that factors with a more local scope of action also play a role, throughout the study area. Local characteristics in the three northwestern European metropolitan environments 
could be similar enough to influence fertility organisation in the same way. These characteristics, organised into two main groups - the compositional and contextual effects - should be considered in studying this phenomenon.

The (intra-)urban spatial segregation of socio-economic, cultural, and migrant-background minorities alter demographic composition from one neighbourhood to another. Moreover, despite various correlations (because of interacting factors), there is a substantial body of literature acknowledging the influence of individuals' characteristics on fertility (see Balbo et al. 2013 for a literature review). Among many other factors are women's employment and earnings (Bernhardt, 1993; Brewster, Rindfuss, 2000; Andersson, 2000), education (Hoem et al., 2006; Kravdal, Rindfuss, 2008), moral values (Surkyn, Lesthaeghe, 2004), migration origin (Haug et al., 2002; Genereux, 2007), and selection and adaptation of (international and internal) migrants regarding their reproductive behaviour (Sobotka, 2008a; Kulu, Milewski, 2007). However, if only some of these (statistical) analyses' study scope exceeds a single country, very few distinguish urban environments, as noted by Kulu and Boyle (2009).

The environment is supposed to have an influence as well, through infrastructure or composition. The degree of urbanisation has already been mentioned in the literature: low fertility at the core could be associated with a different labour market, higher opportunity costs, and the presence of alternatives to family life (Hank, 2002; Fiori et al., 2014). Higher fertility in the suburbs might be a manifestation of a more family-friendly outlook in general in the suburbs (housing stock, schools, pollution) (Kulu, Boyle, 2009). Finally, the composition becomes contextual if women or couples adapt their fertility (intention) to fit local norms. Social networks' (or neighbours') outlooks and recommendations could affect fertility patterns (Bernardi et al., 2007). Hypothetically, the diversity of patterns in cities would be opposed to more normative behaviour in the suburbs, partly induced by the higher proportion of families with children in the suburbs and the associated familyoriented values.

Despite the difficulty of gathering comparable data at a fine spatial level in seven different countries, this study produced an interesting overview of the spatial distribution of fertility intensity and timing in northwestern Europe. It is necessary to know the overriding scales of fertility patterns to hypothesise as to the importance of particular factors. There is a need for more research to test the influence of these factors on fertility using multi-country local data. 


\section{Acknowledgements}

Previous version of this paper has been presented at Chaire Quetelet (2015). I am grateful to the participants at this meeting, Jean-Michel Decroly, Jean-Pierre Grimmeau and the reviewers from Revue Quetelet/ Quetelet Journal for valuable comments.

\section{References}

ANDERSSON G. (2000), «The Impact of Labor-Force Participation on Childbearing Behavior: Pro-cyclical Fertility in Sweden during the 1980s and the 1990s», European Journal of Population, 16 (4), pp. 293-333.

Avdeev A., Eremenko T., Festy P., Gaymu J., Le Bouteillec N., Springer S. (2011), «Populations et tendances démographiques des pays européens (1980-2010)», Population, 66 (1), pp. 9-133, https://doi.org/10.3917/popu.1101.0009.

Bajos N., FerRand M. (2006), "L'interruption volontaire de grossesse et la recomposition de la norme procréative», Sociétés Contemporaines, 1 (61), pp.91-117, https://doi.org/10.3917/soco.061.0091.

Balbo N., Billari F. C., Mills M. (2013), «Fertility in Advanced Societies: A Review of Research», European Journal of Population, February, 29 (1), pp. 1-38.

BASTEN S., HUININK J., KLÜSENER S. (2011), «Spatial Variation of Sub-national Fertility Trends in Austria, Germany and Switzerland», Comparative Population Studies, 36 (2-3), pp. 573-614.

Bernardi L., Keim S., Von Der Lippe H. (2007), «Social Influences on Fertility: A Comparative Mixed Methods Study in Eastern and Western Germany", Journal of Mixed Methods Research, 1 (1), pp. 23-47, https://doi.org/10.1177/234567890629 2238.

Bernhardt E. (1993), "Fertility and Employment», European Sociological Review, 9, (1), pp. 25-24.

BillaRI F., KoHLeR H.-P. (2004), "Patterns of Low and Lowest-Low Fertility in Europe», Population Studies, 58 (2), pp. 161-176, https://doi.org/10.1080/0032472 042000213695.

BreWSTER K., RINDFUSS R. (2000), «Fertility and Women's Employment in Industrialized Nations», Annual Review of Sociology, 26, pp. 271-296, https://doi.org/10. 1146/annurev.soc.26.1.271.

CAStLes F. (2003), «The World Turned Upside Down: Below Replacement Fertility, Changing Preferences and Family-Friendly Public Policy in 21 OECD Countries», Journal of European Social Policy, 13 (3), pp. 209-227, https://doi.org/10.1177/095 89287030133001. 
Coleman D. (2002), «Populations of the Industrial World: A Convergent Demographic Community?», International Journal of Population Geography, 8 (5), pp. 319-344.

Costa R., Eggerickx T., Sanderson J.-P. (2011), «Les territoires de la fécondité en Belgique au 20ème siècle. Une approche longitudinale et communale», Espace, Populations, Sociétés, 2, pp. 353-375, https://doi.org/10.4000/eps.4550.

DeCroly J.-M., GrasLand C. (1992), «Frontières, systèmes politiques et fécondité en Europe», Espace, Populations, Sociétés, 10 (2), pp. 135-152, https://doi.org/10. 3406/espos.1992.1521.

Decroly J.-M., Grimmeau J.-P. (1996), «Les fluctuations de la fécondité en Europe : États et régions», Espace, Populations, Sociétés, 14 (1), pp. 79-91, https://doi.org/ 10.3406/espos.1996.1731.

Decroly J.-M., Vanlaer J. (1991), Atlas de la population européenne, Éditions de I'Université de Bruxelles. $172 \mathrm{p}$.

Desplanques G. (2011), "Les disparités géographiques de fécondité en France», Espace, Populations, Sociétés, 3, pp. 459-473, https://doi.org/10.4000/eps.4649.

Diprete T. A., Morgan S. P., Engelhardt H., Pacalova H. (2003), «Do Cross-National Differences in the Costs of Children Generate Cross-National Differences in Fertility Rates?», Population Research and Policy Review, 22 (5-6), pp. 439-477, https:// doi.org/10.1023/b:popu.0000020961.89068.91.

Douglass C. B. (2007), «From Duty to Desire: Emerging Adulthood in Europe and Its Consequences», Child Development Perspectives, 1 (2), pp. 101-108, https://doi. org/10.1111/j.1750-8606.2007.00023.x.

Ekert-Jaffé O., Joshi H., Lynch K., Mougin R., Rendall M. (2002), «Fécondité, calendrier des naissances et milieu social en France et en Grande-Bretagne», Population, 57 (3), pp. 485-518, https://doi.org/10.3917/popu.203.0485.

FIORI F., Graham E., Feng Z. (2014), "Geographical Variations in Fertility and Transition to Second and Third Birth in Britain», Special Issue "Fertility over the Life Course», Advances in Life Course Research, 21, September, pp. 149-167, https:// doi.org/10.1016/j.alcr.2013.11.004.

Gastner M. T., Newman M. E. (2004), «Diffusion-Based Method for Producing Density-Equalizing Maps», Proceedings of the National Academy of Sciences of the United States of America, 101 (20), pp. 7'499-7'504.

Genereux A. (2007), "A Review of Migration and Fertility Theory Through the Lens of African Immigrant Fertility in France», Working Paper, MPIDR, 008, 74 p., https://doi.org/10.4054/mpidr-wp-2007-008.

Gomes C., De Oliveira I., Pinto M., Cabrita M. (2012), «Fertility, Full-time and Parttime Female Employment in Europe», CIES e-Working Paper, 125, 26 p. 
Grimmeau J.-P., Decroly J.-M. (2003), «Les spécificités urbaines des comportements démographiques en Europe : la mortalité et la fecondité», T. EGGERICKX, C. GouRBIN, B. Schoumaker, C. VAndeschrick, E. VILQuin, Proceedings of the Conference Chaire Quetelet, Populations et défis urbains, 28-29 October 1999, Université Catholique de Louvain,Louvain-La-neuve, Belgium, pp.535-559, https://doi.org/10.7202/ 010281ar.

HaNk K. (2001), «Regional Fertility Differences in Western Germany: An Overview of the Literature and Recent Descriptive Findings", International Journal of Population Geography, 7 (4), pp. 243-257, https://doi.org/10.1002/ijpg.228.

HANK K. (2002), «Regional Social Contexts and Individual Fertility Decisions: A Multilevel Analysis of First and Second Births in Western Germany», European Journal of Population/Revue européenne de Démographie, 18 (3), pp. 281-299, https://doi. org/10.2139/ssrn.380761.

haug W., Compton P., Courbage Y. (2002), Les caractéristiques démographiques des populations immigrées, Études démographiques, 38, Strasbourg, Éditions du Conseil de l'Europe, $608 \mathrm{p}$.

Hoem J. (1990), "Social Policy and Recent Fertility Change in Sweden» Population and Development Review, 16 (4), pp. 735-748, https://doi.org/10.2307/1972965.

Hoem J. M., Neyer G. R., ANDersson G. (2006), «Education Attainment and Ultimate Fertility among Swedish Women Born in 1955-59», Demographic Research, 14 (16), pp. 381-404, https://doi.org/10.4054/demres.2006.14.16.

JONES G. W. (1993), "Is Demographic Uniformity Inevitable?», Journal of the Australian Population Association, 10 (1), pp. 1-16.

KalWIJ A. (2010), «The Impact of Family Policy Expenditure on Fertility in Western Europe», Demography, 47 (2), pp. 503-519, https://doi.org/10.1353/dem.0.0104.

KLÜSener S., Neels K., Kreyenfeld M. (2013), «Family Policies and the Western European Fertility Divide: Insights from a Natural Experiment in Belgium», Population and Development Review, 39 (4), pp.587-610, https://doi.org/10.1111/j.17284457.2013.00629.x.

Kravdal $\varnothing$., Rindfuss R. R. (2008), «Changing Relationships between Education and Fertility: A Study of Women and Men Born 1940 to 1964», American Sociological Review, 73 (5), pp. 854-873, https://doi.org/10.1177/000312240807300508.

KUIJSTEN A. C., (1996), «Changing Family Patterns in Europe: A Case of Divergence?», European Journal of Population/Revue européenne de Démographie, 12 (2), pp. 115-143.

Kulu H., Boyle P. (2009), «High Fertility in City Suburbs: Compositional or Contextual Effects?», European Journal of Population, 25 (2), pp. 157-174, https://doi.org/ 10.4054/mpidr-wp-2007-034. 
KULU H., Milewskı N. (2007), «Family Change and Migration in the Life Course: An Introduction», Demographic Research, 17 (19), pp.567-590, https://doi.org/10. 4054/demres.2007.17.19.

Kulu H., Vikat A., Andersson G. (2007), «Settlement Size and Fertility in the Nordic Countries», Population Studies, 61 (3), pp. 265-285, https://doi.org/10.1080/ 00324720701571749.

Lesthaeghe R., Neels K. (2002), «From the First to the Second Demographic Transition: An Interpretation of the Spatial Continuity of Demographic Innovation in France, Belgium and Switzerland", European Journal of Population/Revue européenne de démographie, 18 (4), pp. 325-360, https://doi.org/10.1023/a:10211258000 70.

Lesthaeghe R., Permanyer I. (2014), «European Sub-Replacement Fertility: Trapped or Recovering?», Population Studies Center Research Report, 14 (822), 37 p.

Lesthaeghe R., VAN DE KaA D. J. (1986), "Twee demografische transities?», D. J. VAN DE KAA, R. LeSthaeghe (eds), Bevolking: Groei en Krimp. Van Loghum Slaterus, Deventer, 9-24,Mens en Maatschappij, Boekaflevering, jrg. 61, https://doi.org/10. 5117/mem2010.4.popp.

LUCI-Greulich A., Thévenon O. (2013), «The Impact of Family Policies on Fertility Trends in Developed Countries", European Journal of Population/Revue européenne de Démographie, 29 (4), pp.387-416, https://doi.org/10.1007/s10680-0139295-4.

Prince Cooke L., BAXTeR J. (2010), “'Families' in International Context: Comparing Institutional Effects across Western Societies», Journal of Marriage and Family, 72 (3), pp. 516-536, https://doi.org/10.1111/j.1741-3737.2010.00716.x.

Rindfuss R., Choe M., Brauner-Otto S. (2016), «The Emergence of Two Distinct Fertility Regimes in Economically Advanced Countries», Population Research and Policy Review, 35 (3), pp. 287-304, https://doi.org/10.1007/s11113-016-9387-z.

Rousset L. (1992), «La famille en Europe occidentale : divergences et convergences», Population, 47 (1), Janvier-Février, pp. 133-152, https://doi.org/10.2307/ 1533635.

SARDON J.-P. (2009), "La fécondité en Europe, éléments pour une typologie», Estudios Geográficos, 70 (267), pp. 599-631, https://doi.org/10.3989/estgeogr.0466.

Sовотка T. (2008a), "Overview Chapter 7: The Rising Importance of Migrants for Childbearing in Europe», Demographic Research, 19 (9), pp. 225-248, https://doi. org/10.4054/demres.2008.19.9.

Sовотка T. (2008b), "Overview Chapter 6: The diverse faces of the Second Demographic Transition in Europe», Demographic Research, 19 (8), pp. 171-224, https:// doi.org/10.4054/demres.2008.19.8.

SовоткA T., AdigüZel F. (2002), «Religiosity and Spatial Demographic Differences in the Netherlands», s.n., 23 p. 
SURkyn J., Lesthaeghe R. (2004), "Value Orientations and the Second Demographic Transition (SDT) in Northern, Western and Southern Europe: An Update», Demographic Research, Special Collection, S3 (3), pp. 45-86, https://doi.org/10.4054/ demres.2004.s3.3.

Thévenon O. (2011), "Family Policies in OECD Countries: A Comparative Analysis», Population and Development Review, 37 (1), pp. 57-87, https://doi.org/10.1111/j. 1728-4457.2011.00390.x.

Thévenon O., Gauthier A. (2011), "Family Policies in Developed Countries: A 'Fertility-Booster' with Side-Effects», Community, Work and Family, 14 (2), pp. 197-216, https://doi.org/10.1080/13668803.2011.571400.

Valkonen T., Blomgren J., Kauppinen T. M., Martikainen P., MäenpäÄ E. (2008), «The Effects of Socioeconomic and Cultural Characteristics of Regions on the Spatial Patterns of the Second Demographic Transition in Finland", Demographic Research, 19 (61), pp. 2'043-2'056, https://doi.org/10.4054/demres.2008.19.61.

VAN De KaA D. J. (1987), «Europe's Second Demographic Transition», Population Bulletin, 42 (1), pp. 1-59.

VAN DE KAA D. J. (1994), "The Second Demographic Transition Revisited: Theories and Expectations», G. C. N. Beets, J. C. van Den BREKEL, R. L. Cliquet, G. Dooghe, J. DE Jong GIERVELD (eds), Population and Family in the Low Countries 1993: Late Fertility and Other Current Issues, Swets and Zeitlinger, Lisse, NIDI CBGS Publications, 30, pp. 81-126, https://doi.org/10.2307/1534110.

Veltz P. (1996), Mondialisation, villes et territoires. L'économie d'archipel, Presses universitaires de France, Collection Économie en liberté, Paris, 264 p.

WANNer P. (2000), "L'organisation spatiale de la fécondité dans les agglomérations : Le cas de la Suisse 1989-1992», Geographica Helvetica, 55 (4), pp. 238-250, https://doi.org/10.5194/gh-55-238-2000.

WatkInS S. C. (1991), From Provinces into Nations: Demographic Integration in Western Europe, 1870-1960, Princeton, NJ, Princeton University Press, https://doi. org/10.1086/ahr/97.2.544-a. 